\title{
Privatised Keynesianism and the state-enhanced diversification of credit: the case of the French housing market
}

\section{Gertjan Wijburg}

To cite this article: Gertjan Wijburg (2019) Privatised Keynesianism and the state-enhanced diversification of credit: the case of the French housing market, International Journal of Housing Policy, 19:2, 143-164, DOI: 10.1080/19491247.2017.1397926

To link to this article: https://doi.org/10.1080/19491247.2017.1397926

曲制 Published online: 10 Jan 2018.

Submit your article to this journal $\widetilde{ }$

Џll Article views: 220

Q View related articles $\widetilde{ }$

View Crossmark data $\nearrow$

Citing articles: 1 View citing articles $₫$ 


\title{
Privatised Keynesianism and the state-enhanced diversification of credit: the case of the French housing market
}

\author{
Gertjan Wijburg
}

Department of Geography \& Tourism, KU Leuven/University of Leuven, Leuven, Belgium

\begin{abstract}
In 2008, it became clear that the pre-crisis growth model of privatised Keynesianism was at least temporarily undermined by the global financial crisis. Instead, housing scholars started pointing out that the combination of reduced home ownership and the resurgence of private landlordism indicated a shifting approach to housing wealth in capitalist societies. However, this research on the housing market of France demonstrates that the rise of private landlordism does not necessarily undermine home ownership. Unlike in many other European countries, pre-crisis credit expansion in France was not only targeted at homeowners, but also at private landlords and buy-to-let investors that used state-authorised credit loans to fund investments in the private rental sector. Because the rise of private landlordism in France has rather complemented than undermined home ownership, this paper shows that privatised Keynesianism in France has both linked homeowners and private landlords to extensive housing debt.
\end{abstract}

KEYWORDS Privatised Keynesianism; private landlordism; home ownership; asset-based welfare; France

\section{Introduction}

Over the past decade or so, various housing scholars have addressed how housing markets in Western Europe, the United States and emerging economies have become widely integrated in and through global financial markets (Aalbers, 2016; Jordá, Schularick, \& Taylor, 2014). Privatised Keynesianism has become a central concept for understanding this development and refers to a 'system of markets alongside extensive housing and other debt among lowand medium-income people linked to unregulated derivatives markets' (Crouch, 2009, p. 382). Although privatised Keynesianism is typically perceived as a finance-led growth regime in which public debt of governments is replaced by private debt of corporations and households (Crouch, 2011), housing scholars have pointed out that the extensive growth of mortgage 
debt associated with this regime is often fiscally and financially encouraged by governments that seek to switch households from the public housing sector into the private sector (see e.g. Jacobs \& Manzi, 2017; Watson, 2010). Therefore, privatised Keynesianism or 'house price Keynesianism' can also be perceived as a partially state-enhanced asset-based welfare regime in which households can compensate for reduced income and welfare by continually trading up the value of their housing assets (Aalbers \& Christophers, 2014; Watson, 2010).

Nonetheless, various housing scholars have started pointing out that the pre-crisis growth regime of privatised Keynesianism was at least temporarily undermined in the aftermath of the global financial crisis (GFC) (Aalbers, 2015; Crouch, 2011). While housing markets across the advanced, capitalist world collapsed and wider access to home ownership decreased, asset-based welfare through owner-occupied housing seemed to be out of reach for wide strata of the population (Forrest \& Hirayama, 2015; Ronald, Lennartz, \& Kadi, 2017). Instead, the combination of reduced homeownership and the resurgence of private landlordism was seen as a shifting approach to housing wealth and welfare security (Forrest \& Hirayama, 2009; Ronald \& Kadi, 2016). Furthermore, the shift to private landlordism was accompanied by a rather extreme intergenerational housing wealth polarisation between older generations and younger adults (Arundel, 2017; Kemp, 2015). Or, as Ronald et al. (2017, p. 174) put it: ' the resurgence of private renting [is] driven by growing demand among younger adults excluded from home ownership, and the buying up of housing to let by those already embedded in the market'.

Although this paper recognises this regressive trend in advanced, capitalist societies, it still considers the rise of private landlordism as an integral part of the pre-crisis growth regime of privatised Keynesianism. First, this paper calls for a more holistic conceptualisation of privatised Keynesianism as a regime that not only turns homeowners into 'modern investment subjects' (Watson, 2010). Far more than a policy regime that merely promotes mortgaged home ownership, privatised Keynesianism is a flexible regime of accumulation, which potentially links different kinds of households to housing debt, including private landlords (Crouch, 2011; Fernandez \& Aalbers, 2016). Second, this paper argues that the resurgence of private landlordism must not be perceived as a undermining, but rather as a deepening of privatised Keynesianism, even though it is accompanied by reduced asset-based welfare opportunities (cf. Ronald et al., 2017). While previous generations of homeowners that have benefited from rising house prices in the past are now switching their previously accumulated housing wealth into the private rental sector, privatised Keynesianism is essentially reconstituting itself by expanding into another segment of the market (Kemp, 2015). However, since national housing markets are unevenly developed 'systems in motion', this more regressive phase of privatised Keynesianism is not as strong in all 
national housing systems, i.e. is variegated across time and space (cf. Fernandez \& Aalbers, 2016).

In order to make this argument, this paper revolves around a national case study of the French housing market which is traditionally known for statedevelopmentalism, a hybrid housing structure and relatively low mortgage debt and home ownership levels (Driant, 2010; Schwartz \& Seabrooke, 2009). Nonetheless, the French housing system can be seen as an perfect example of how privatised Keynesianism can link both homeowners and private landlords to extensive housing debt (Trouillard, 2014). Following various housing reforms in the 1970s and the 1980s, the French developmental state progressively reduced its subsidies to the social housing sector and introduced new housing policies to boost the private housing sector (Driant, 2010; Gobillon \& le Blanc, 2008). Rather than merely supporting home ownership, French-style privatised Keynesianism also promoted private landlordism in the private rental sector. Therefore, pre-crisis debt expansion in France was not mainly targeted at homeowners, but also at private landlords and buy-to-let investors that funded the production of new private rental homes (Gobillon \& le Blanc, 2008; Pollard, 2010b). Or, as the French economist Alain Lipietz (2013, p. 11) puts it: 'the real estate bubble occurs... but its mechanism is much more "monopolistic", that is to say, controlled. The loans come from banks, not from brokers, and go to owner-occupiers, but also to private landlords'.

First, by reconstructing France's pathway to privatised Keynesianism and a diversified credit system, this paper contributes to the ongoing yet loosely connected debates on privatised Keynesianism, private landlordism and the financialisation of housing in advanced, capitalist societies (see e.g. Aalbers, 2016; Crouch, 2009; Ronald et al., 2017; Wijburg \& Aalbers, 2017a). In doing so, it not only shows that privatised Keynesianism can link different kinds of households to extensive housing debt, but also that the regressive turn to private landlordism in post-crisis housing systems is variegated across time and space (Fernandez \& Aalbers, 2016; Schwartz \& Seabrooke, 2009). Second, by highlighting how commercial banks and private property developers use the money from private landlords to construct new housing units, this paper also highlights an important supply-side characteristic of privatised Keynesianism that is often disregarded by the literature (but see Romainville, 2017; Sanfelici \& Halbert, 2016). In other words, this paper presents a national case study where besides commercial banks also private property developers play a key role in sustaining privatised Keynesianism (see also Pollard, 2011; Van Loon, 2016).

In the next section, this paper develops the argument that, rather than two fundamentally different approaches to housing wealth, home ownership and private landlordism are crucial part of the same growth regime: privatised Keynesianism (cf. Fernandez \& Aalbers, 2016). Subsequently, this paper reconstructs the advent of privatised Keynesianism in France by reflecting on the legacy of housing policies and on the increased connections between French 
commercial banks and the domestic property sector (Pollard, 2007; Tutin \& Vorms, 2014). Thereafter, this paper concludes that for the moment private landlordism and home ownership in France do not undermine, but rather complement each other. Nonetheless, it is not inconceivable that the French housing system will move in the same direction as the United Kingdom in the near future: the number of private landlords is increasing faster than the number of new homeowners that take mortgages.

\section{Privatised Keynesianism as a flexible regime of accumulation}

Privatised Keynesianism has become widely known as the unacknowledged but neoliberal successor of Keynesianism-Fordism: a policy regime in which households, rather than the state, take up credit to stimulate the economy (Aalbers \& Christophers, 2014; Crouch, 2009). While the advent of privatised Keynesianism was strongly tied to national housing systems, the literature has shown that a secular tendency towards higher mortgage debt levels and house price inflation can be observed in most advanced, capitalist societies (Andrews, Sánchez, \& Johansson, 2011; Jordá et al., 2014). Yet, the extensive growth of mortgage debt among households cannot be attributed to 'financial deregulation' alone. In practice national governments still provide fiscal and financial support to the promotion of home ownership as they aim to shift tenants from the public to the private housing sector (Watson, 2010). Privatised Keynesianism or 'house price Keynesianism' has a potential advantage: increasing housing wealth through debt-fuelled house price inflation can compensate households for reduced income as long as house prices remain stable or keep on growing and credit remains available (Crouch, 2011; Watson, 2010). However, since privatised Keynesianism also links households to global financial markets, it is not a system without risks (Hay, 2011; Waldron \& Redmond, 2017).

In theory, privatised Keynesianism can link different kinds of households to extensive housing debt (Crouch, 2011; Wainwright, 2009). Nonetheless, the literature has barely linked the advent of privatised Keynesianism to developments in the private rental sector (but see Kemp, 2015; Ronald \& Kadi, 2016). To a large extent, this can be explained by the fact that the private rental sector is dominantly perceived as a tenure option, and not as a welfare strategy (Kemp \& Kofner, 2010; Soaita et al., 2017). First, rental regulations and tenant security has made it traditionally more difficult for private landlords to profit from house price increases, although market reforms across advanced, capitalist societies have also liberalised the private rental sector, especially in the United Kingdom (Kemp, 2015; Ronald, 2008). Second, private landlords have traditionally funded housing acquisitions with private equity and not with debt, which suggests that private landlords do not invest in housing with the intention to profit from capital gains (Kemp \& Kofner, 2010). 
However, a burgeoning literature in the United Kingdom and other posthomeownership societies has shown that private landlords have recently taken up large sums of housing debt as a means to fund new housing acquisitions (Forrest \& Hirayama, 2015; Soederberg, 2017). Also, the literature has highlighted that the number of private landlords, as well as the number of their activities, have increased significantly from the mid 2000s onward in countries as varied as the United Kingdom, United States, Japan and Australia (Arundel, 2017; Forrest \& Hirayama, 2015; Ronald et al., 2017). Nonetheless, the resurgence of private landlordism is often seen as a trend that undermines, rather than complements, privatised Keynesianism. Because the resurgence of private landlordism in most English speaking countries is accompanied by reduced home ownership, it is sometimes believed that private landlordism indicates a shifting approach to housing welfare characterised by a rather extreme intergenerational housing dualisation (Ronald \& Kadi, 2016). In fact, most private landlords are effectively 'arrived' homeowners that let out private rental homes to younger adults whose access to owner-occupied housing has decreased in the wake of the GFC (Arundel, 2017; Ronald et al., 2017).

Although this paper recognises this regressive element, it still considers the rise of private landlordism as an integral part of privatised Keynesianism. First and foremost, private landlordism was along with home ownership an important policy objective of pre-crisis privatised Keynesianism (Haffner, Elsinga, \& Hoekstra, 2008; Kemp, 2015). While facing a public budget crisis in the 1970s, national governments imposed restrictions on public expenditure to the social rental sector and introduced new housing policies to stimulate the private rental sector (Harloe, 1995; Jacobs \& Manzi, 2017). For instance, the introduction of buy-to-let loans and tax subsidies to private landlords was an important political instrument to reduce a tight supply of housing (Aalbers, 2015; Vergriete, 2013). In other words, as it linked housing production to the agency of private actors, privatised Keynesianism also developed a strong supply-side component in which private landlords would play a key role (Gibb \& Nygaard, 2005; Pollard, 2010b).

Second, the dominant idea that privatised Keynesianism and the financialisation of housing linked mostly homeowners to extensive housing debt during the pre-crisis credit cycle, has proven to be empirically inaccurate (Kemp, 2015). First, while commercial banks sought for new sources of borrowers in the mid 2000s, credit expansion was also targeted at private landlords and other private actors (Forrest \& Hirayama, 2015; Soederberg, 2017). Second, while private landlords discovered how to make competitive profits in the private rental sector, they were turned into 'modern investment subjects' too (Langley, 2006; Watson, 2010). This is, inter alia, reflected in the financial strategies that private landlords use to trade up the value of their assets and to increase their rental income (cf. Soaita et al., 2017). 
Third, since it requires expanded home ownership to make the transition to private landlordism possible, the resurgence of private landlordism across capitalist societies can be understood as a deepening of privatised Keynesianism, rather than as its necessary end point (Ronald et al., 2017). To put it differently, the switch from home ownership to private landlordism is de facto a reconstitution and continuation of privatised Keynesianism, however in another segment of the market and with reduced asset-based welfare opportunities (Ronald et al., 2017). Yet, since varieties between national housing systems persist, the rate and degree of this more regressive phase of privatised Keynesianism is uneven and variegated across countries (Christophers, 2013; Fernandez \& Aalbers, 2016). Most particularly, in countries where multiple tenure options are prevailing, the increase of private landlordism does not necessarily undermine the home ownership project (see also Schwartz \& Seabrooke, 2009).

To demonstrate this point, the next section will focus on the advent of privatised Keynesianism in France. Although the French market is known for moderate mortgage debt levels and a hybrid market structure, strong evidence suggests that the rise of home owners and private landlordism is an essential characteristic of French-style privatised Keynesianism. For instance, the number of French homeowners rose from 10.7 million in 1984 to 16.4 million in 2013. Although only 4.9 million of these homeowners had a mortgage in 2013, mortgage debt levels as a percentage of GDP increased from $20 \%$ in 1995 to $40 \%$ in $2012 .^{2}$ Similarly, the number of private landlords increased from 5.4 to 6.5 million between 1984 and 2013. Comparative data show that the total nominal amount of mortgage debt from private landlords increased from 2 billion euro to 20 billion euro between 1984 and 2013.

To reconstruct the advent of privatised Keynesianism in France, this paper focuses on several housing reforms by the French government and also on the role of commercial banks and private property developers that offer financial services to homeowners and private landlords. The analysis builds on housing data from the Compte du Logement that covers the period 1984 to 2014. Figure 1 shows the total amount of government subsidies of the French state to housing between 1984 and 2014. Here we must distinguish between the 'aid to bricks and mortar', i.e. supply-side subsidies to social housing construction, the 'personal aid', which includes demand subsidies to homeowners and tenants in the private and social sector, and 'fiscal aid', which includes subsidies to homeownership and tax incentives to promote buy-to-let investments and to stimulate private housing construction (Driant, 2010). Although post-war housing policies historically prioritised the aid to 'bricks and mortar', the 'personal aid' and 'fiscal aid' gained prominence from the 1980s onward. ${ }^{3}$ The main part of the 'fiscal aid' is made up of various modes of reduced VAT to support the activity of the construction sector. 


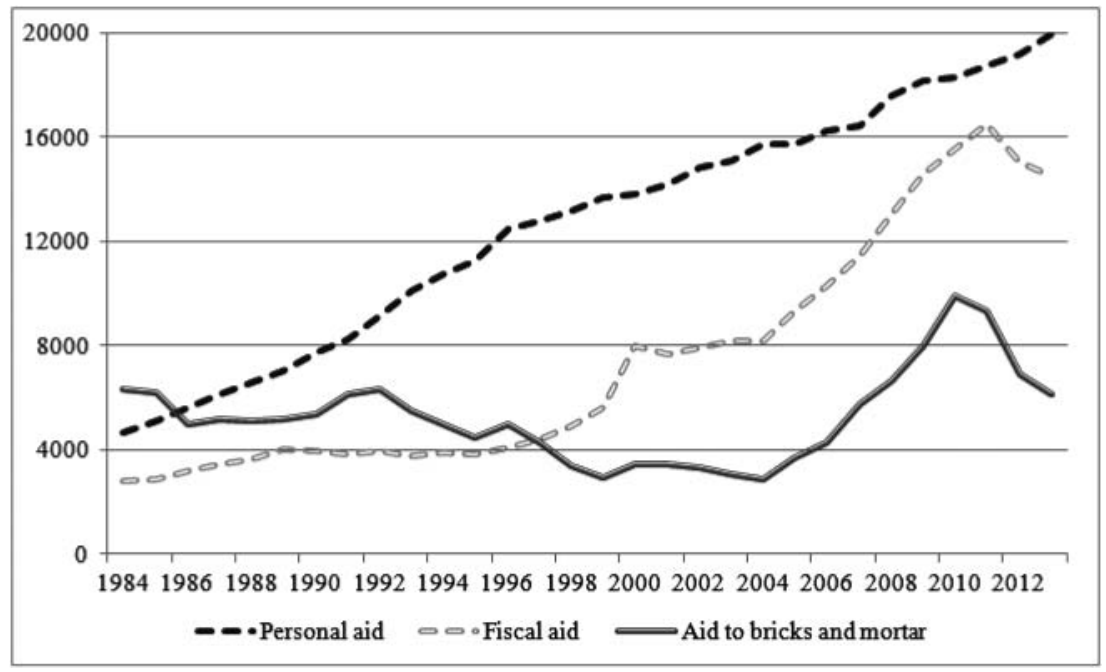

Figure 1. Government subsidies to housing in EUR millions, 1984-2013. Source: Compte du Logement, 2015.

\section{Promoting home ownership in France}

With around 400,000 houses in France destroyed and around two million severely damaged during the Second World War, post-war French housing politics responded to the need to tackle the housing shortage in the country (Blanc, 2004). In doing so, the state (re)established a financial network around the Treasury and the (semi)-public bank of the Caisse des Dépôts et Consignations (CDC). The CDC collected savings from households through traditional savings accounts and deposits (Shonfield, 1965). The government used its public bank to offer favourable loans and monetary support to the social housing sector, collectively known as the HLM (Habitation à loyer modéré). The funding of public housing happened mainly through fiscal subsidies and mortgage loans with a favourable interest rate (Driant, 2010).

However, around the time of the First Oil Crisis in 1973, criticism against the 'aid to bricks and mortar' increased. First, the lacking quality of many housing estates and the gigantic proportions of many high-rise buildings triggered a debate whether homeownership was preferable to rental housing (Blanc, 2010). This debate was also inflicted by the enduring problems with inner city slums and the disappointing results of the social experiments with high-rise buildings in the grands ensembles around Paris and other metropolitan regions (Driant \& Li, 2012; Levy \& Fijalkow, 2010). Second, due to the slowdown of the economy and the First Oil crisis, government expenditure to welfare and social housing was also widely debated in France (Bourdieu, 2000; Pollard, 2010b). Much like in Great Britain, the gravity in housing policies shifted to imposing restrictions on public expenditure to social housing 
and launching private housing construction (Effose, 2003; Jacobs \& Manzi, 2017).

It was under the administration of President Giscard D'Estaing and Prime Minister Barre when a new housing reform was implemented in 1977. While the French Treasury was traditionally in favour of funding the HLM, a new elite of state officials in the Ministry of Transport and Planning introduced the new policies of 'personal aid' (Bourdieu, 2000). Rather than extending the construction of social housing through the financial network established by the CDC, the new state officials actively sought to provide demand subsidies to homeowners and tenants in the private sector (Pollard, 2010b). The 'personal aid' was implemented to make this group of citizens solvent enough to enter this market (Driant, 2010). Depending on income and family circumstances, households would gain financial support to choose between different types of housing tenure, including the private rental market and the owner-occupied segment (Blanc, 2004; Bourdieu, 2000). ${ }^{4}$

Although the largest part of the 'personal aid' consisted of housing benefits for tenants in the private and social rental sector, homeownership subsidies were also introduced (Driant, 2010). An important component of the 'personal aid' was the so-called 'authorised mortgage loan' or PC (prêt conventionné), which encouraged homeownership among especially low income households (Blanc, 2004). A specific type of such a authorised mortgage loan was the PAP (prêt d'accession à la propriété) which was extended to first-time home buyers. In this construction, the state financed a share of the interest payment to the mortgage bank, providing that the mortgage loan was offered at a fixed rate below market value (Driant, 2010).

In 1995, the French government introduced a new political instrument which has remained in place until today: the zero-interest loan. The prêt à taux-zero (PTZ) replaced the PAP in 1996 and was extended to first-time home buyers with especially a medium income. Contrary to authorised mortgage loans, the zero-interest rate loan is not financed directly by the state, but rather redeemed through a tax allowance (Pollard, 2010b). The maximum of the loan depends on family size, income and the geographical location where the housing unit is located (Gobillon \& le Blanc, 2008). The value of the loan may typically not exceed $20 \%$ of the total value of the dwelling and may not account for more than $50 \%$ of the total amount of credit (Gobillon \& le Blanc, 2008). From 2005 until 2011, the PTZ could also be used for the acquisition of existing housing units, without any obligations to carry out repairs or renovations (DGTPE, 2010; Pollard, 2010a).

The increased importance of state-authorised mortgage loans over the years has been displayed in Figure 2. Between 1984 and 1990, the total expenditure on authorised mortgage loans reached its highest point. Most of the expenditure on these loans was used by (low-income) households to fund the acquisitions of new homes. After the abolishment of the PAP and 


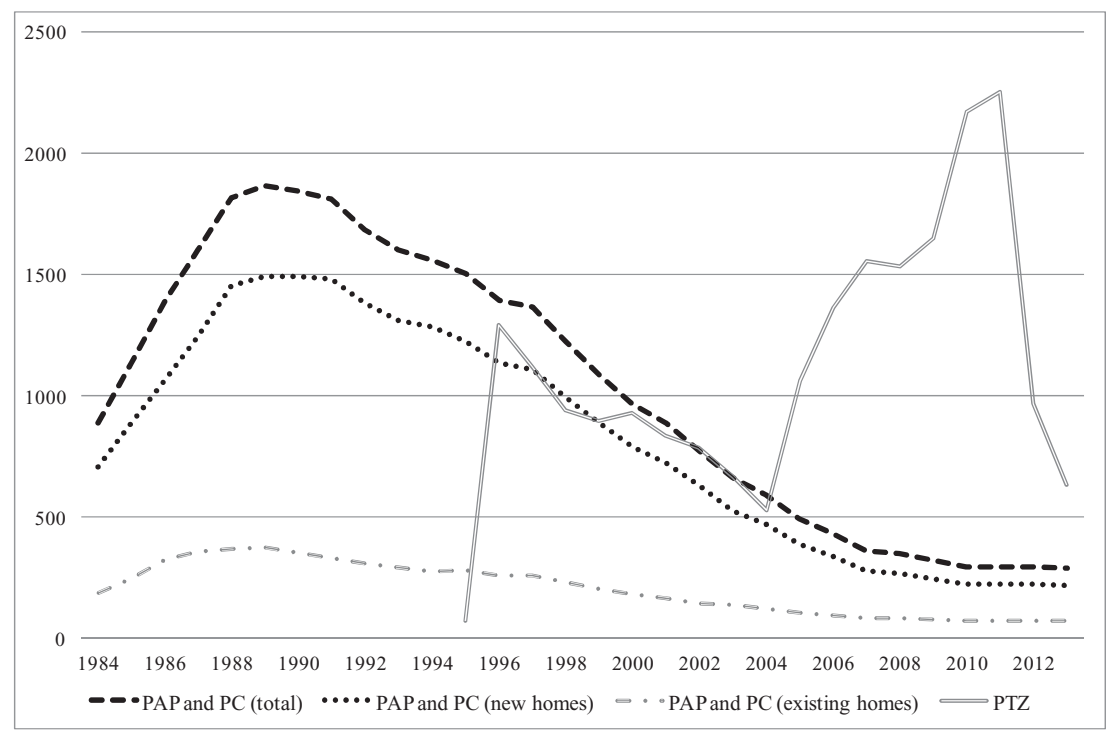

Figure 2. Demand subsidies (PAP and PC) and fiscal subsidies (PTZ) in EUR millions, 1984-2014. Source: Compte du Logement, 2015.

other authorised mortgage loans in 1995, the gradual expansion of the PTZ begins. Overall, the French state has spent between 1 and 2 billion euro annually on promoting homeownership among households during this period. ${ }^{5}$

\section{The increased importance of mortgage banks}

The advent of privatised Keynesianism in France relied heavily on the capacity of the French banking sector to provide authorised mortgage loans to households (Effose, 2003; Trouillard, 2014). In practice, the policies of 'personal aid' strengthened the ties of French mortgage banks (Pollard, 2010b). Regarding market liberalisation, the French government, however, did not choose to fully liberalise the French mortgage sector but rather opted for a shared risk model, in which the state subsidised substantial amounts of mortgage credit, providing that these credit loans would be issued to low-income households (Gobillon \& le Blanc, 2008). Because of this housing policy, French mortgage banks could expand their mortgage activities to a large group of potential new homeowners without necessarily being exposed to high default risks, and simultaneously helping the French government to promote home ownership (Pollard, 2010b).

Between 1977 and 1996, only the Crédit Foncier de France and other Société anonyme de crédit immobilier $(\mathrm{SACl})$ were allowed to distribute stateauthorised mortgage loans to households (Blanc, 2004). However, with the 
introduction of the PTZ in 1996, the recently privatised French commercial banks also obtained the rights to do this (Driant \& Li, 2012; Hardie \& Howarth, 2009). The banking sector in France is relatively unified, despite ongoing liberalisation and internationalisation (Hardie \& Howarth, 2009; Wijburg \& Aalbers, 2017b). At a domestic level, large French banking groups operate at the intersection of mortgage lending, mortgage refinancing and property development (Tutin \& Vorms, 2014). The three largest French banking groups, BNP Paribas, Crédit Agricole and Société Générale own large property companies and are very active in the construction sector (Boccara, 2014). Due to their close connections with the property sector, commercial banks have the ability to coordinate their activities of mortgage lending and property development in a cost-effective way. At the same time, government support and the authorisation of credit loans enabled commercial banks to keep a relatively low-risk profile without becoming overly reliant on new financial practices, such as mortgage securitisation (Boccara, 2014; Hardie \& Howarth, 2009).

Nonetheless, the French housing market experienced an unprecedented surge in house prices during the pre-crisis housing boom of 1995-2007 (Friggit, 2011). Contrary to the housing boom in the 1980s, the most recent housing boom was not limited to the Greater Paris region and also manifested itself in metropolitan regions such as Lyon and Marseille (Davezies, 2012; Tutin \& Vorms, 2014). Interestingly, the increase in French house prices was strongly boosted by the fall of global interest rates and the lenghtening of the duration of mortgage loans (Driant, 2010; Friggit, 2011). Yet, the French housing system did not experience a bust in house prices when the crisis hit (Cusin, 2013; Timbeau, 2013). Furthermore, mortgage debt levels remained comparatively low, despite a strong increase between 1995 and 2012 (Timbeau, 2013). However, the combined debt levels of homeowners and private landlords indicate that the French housing system has become more indebted than is commonly understood (Lipietz, 2013). Therefore, next section will elaborate on the role of private landlords and private property developers in the French housing system.

\section{Promoting private landlordism and buy-to-let investments in France}

During the 1980s, the French government and local authorities started experimenting with the new housing policies of 'fiscal aid' (Vergriete, 2013). Against the background of stagnant economic growth, the policies of fiscal aid were introduced to further restrict public expenditure to the housing sector, but also to promote buy-to-let investments (investissement locatif) in France as a means to boost economic activity and property-led growth (Pollard, 2010b). Rather than encouraging institutional investors to invest in new private housing production, the state mobilised private landlords and other investors to 
do this (Trouillard, 2014). This was also done because many institutional investors were withdrawing from the housing market and were increasingly orienting themselves in the commercial property sector (Bosvieux, 2011).

Much like in the United Kingdom, the introduction of tax allowances enabled buy-to-let investors to deduct large amounts of their investments from their tax income, providing that the housing units invested in are let out in the private rental sector for a number of years (Bosvieux, 2005). Yet, contrary to the United Kingdom, the policies of fiscal aid in France were mainly introduced to boost the construction sector and the production of new homes (Vergriete, 2013). That is to say, state-authorised credit loans were mostly used to fund new housing production and to reduce the tight supply of housing in French metropolitan regions (Gobillon \& le Blanc, 2008). This supply-side characteristic of privatised Keynesianism is an important and distinctive component of the French housing model and also indicates that privatised Keynesianism was never solely about stimulating aggregate demand (but see Romainville, 2017; Sanfelici \& Halbert, 2016).

Between 1996 and 2012, the politics of 'fiscal aid' primarily promoted new housing construction and buy-to-let investments, without imposing substantial requirements on the level of rental charges (Pollard, 2010b). However, a new tax incentive introduced in 2012 was accompanied by a rental ceiling to control rental incomes out of private renting (Scellier \& Le Bouillonnec, 2008). The rental ceiling largely depends on the geographical location where the housing unit is located and seeks to keep buy-to-let rental units accessible for low and medium-income households (Gobillon \& le Blanc, 2008). By making distinctions between different geographical locations, the buy-to-let tax incentives have not only been used to encourage private investments in the French housing system, but also to direct those investments into the most 'overheated' segments of the market in order to keep buy-to-let housing accessible for low and medium income households (Trouillard, 2014).

Because the policies of 'financial aid' essentially introduced tax incentives to invest in buy-to-let housing, private landlords have increasingly perceived investing in private rental homes as a financial strategy to offset for reduced income (Pollard, 2011). As a result, the new fiscal policies have not only boosted new investments in housing but have also contributed to the reinforcement of private landlordism in France, which more than before has become a patrimonial strategy for wealth accumulation (cf. Forrest \& Hirayama, 2015; Soaita et al., 2017). Over the years, private landlords have increased their willingness to take up mortgage debt to finance their housing acquisitions (Bosvieux, 2005). Figure 3 shows that private landlords in France had mostly financed their investments with down payments until the introduction of the 'Périssol tax allowance' in 1996 (Bosvieux, 2005). After the introduction of this tax allowance, mortgage loans became the major source of funding investments in private rental homes (Pollard, 2010a). 


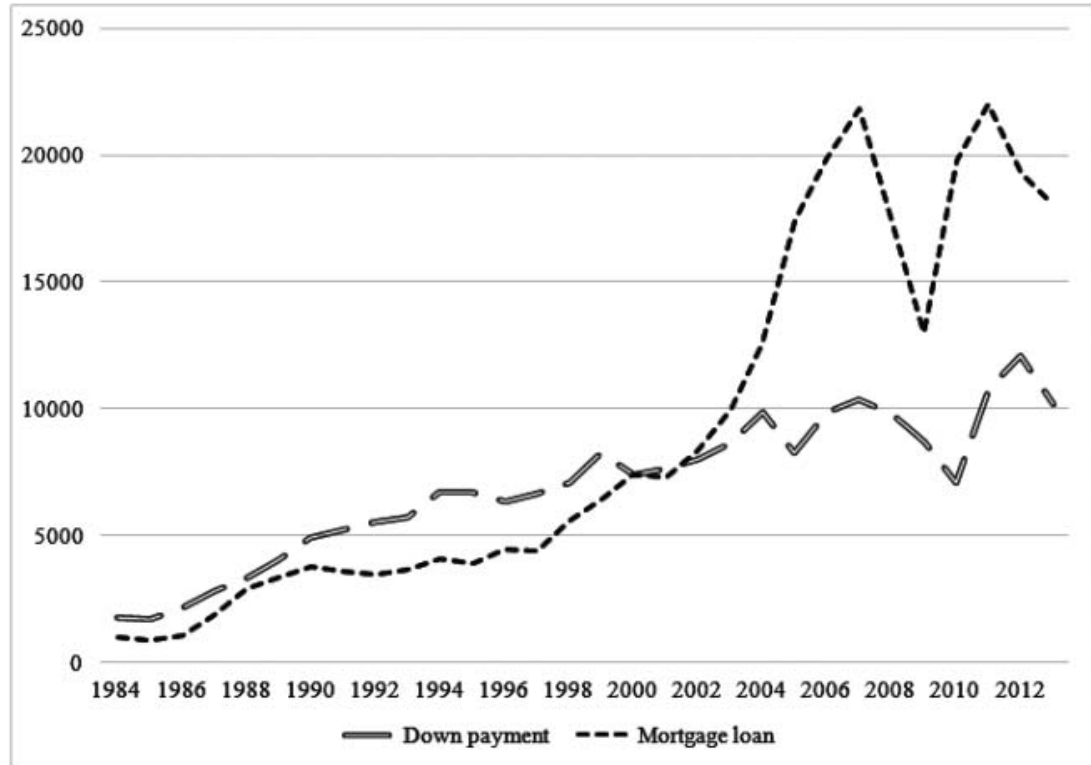

Figure 3. Funding of housing acquisitions by private landlords in EUR millions, 19842013. Source: Compte du Logement, 2015.

Another outcome of the fiscal aid-policies is that investments in the private rental sector have become more responsive to global credit cycles (Driant, 2010). Because buy-to-let investments are typically not only financed with private equity, the credit availability in the French banking sector has become an important variable for determining the annual amounts of buy-to-let investments in France (DGTPE, 2010). Figure 4 shows that buy-to-let investments are rather cyclic than constant: new housing construction went up from 20,000 housing units in 1995 to more than 60,000 housing units in 2005 and even to more than 70,000 housing units in 2010. Interestingly, investments in buy-to-let housing continued to increase after the outbreak of the GFC when a stimulus package, accompanied with new tax incentives, was introduced by the administration of President Sarkozy (Pollard, 2010a).

Regarding the rise of private landlordism, it is important to distinguish between different kinds of private landlords in France. In 2013, around 15\% of French households owned minimal one extra home next to their private residence (Insee, 2017: 134). The majority of these households consists of wealthy and aging couples whose children have left the parental home and who invest in a second home in the Greater Paris region to secure an income for retirement. Around $16 \%$ of the private landlords in France make use of fiscal aid and tax incentives to invest in private rental units (Insee, 2017, p. 155). On average, these private landlords are in their mid forties and earn a annual 


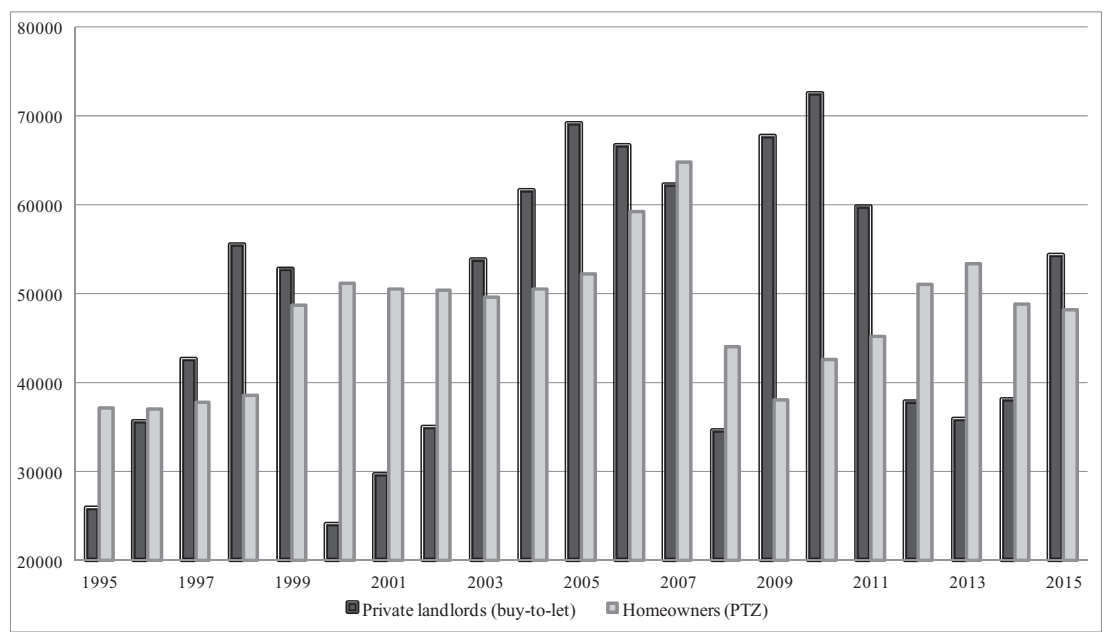

Figure 4. New tax-exempt housing construction in total numbers, 1995-2015. Source: FPI France, 2016.

income of more than 70,000 euro and invest primarily in smaller studios and apartments in the south of France (63\%) and Paris (19\%) (Crédit Foncier, 2017, pp. 8-13). Interestingly, private landlords belonging to the latter group possess in most cases two private rental units, but higher numbers are not uncommon: around $18 \%$ of this group owns more than six buy-to-let homes (Les Echoes, 2015).

\section{The increased importance of private property developers}

Because housing investments are capital-intensive, buy-to-let investments are rarely made without the intervention of property developers that mediate between private investors and local housing markets (Bosvieux, 2005). However, most property companies that offer services to private landlords and other investors are not 'ordinary' developers that specialise in selling and constructing individual housing units. On the contrary, most of these property companies are (partially) owned by financial institutions and/or are listed on the French stock exchange (Trouillard, 2014; Tutin \& Vorms, 2014). Since commercial banks can increase their profitability by combining credit distribution and property development, they have become known for commercialising this niche in the market (Bosvieux, 2005). For instance, commercial banks and sometimes private property developers offer package deals of personal and financial aid on their websites in an attempt to attract new customers and investors (Pollard, 2011; Vergriete, 2013).

Over the past few years, a few large property companies owned by French banking groups have become known for making this business model more 
mainstream. For instance, Nexity, which was partially owned by the banking group of the Caisse D'Epargne and more recently has become part of the banking group BPCE, focused around $66 \%$ of its market activities in 2007 on buy-to-let investments and related services (Pollard, 2007). In 2015, this number was with $43 \%$ still considerably high for the largest listed property company of the country (Nexity, 2015). Other examples of property companies which have adopted similar investment strategies are BNP Paribas Real Estate and Sogeprom, a property company owned by Société Générale. Bouygues, the second largest property company of France, has done the same (Vergriete, 2013).

While large property companies prioritise financial motives, pre-crisis housing construction took mostly place in locations where tax allowances provided the highest return on investments and where substantial rental increases could be charged (Scellier \& Le Bouillonnec, 2008). For instance, only $11.7 \%$ of the total amount of buy-to-let investments during the pre-crisis boom was concentrated in the most 'overheated' Greater Paris region, where the profit rates are relatively low because of high land prices and a tight supply of vacant building plots (Scellier \& Le Bouillonnec, 2008). However, a remarkable number of investments was made in southern France: in the regions of Lyon (16.6\%), Montpellier (11.6\%) and Toulouse (11.2\%), where housing supply is also tight, but not as tight as in Paris. This geographical focus on the south of France was both an economic necessity, but also a financial strategy to locate investments in more profitable regions (Vergriete, 2013).

For similar reasons, medium and smaller property developers were also notorious for investing in smaller cities and mid-sized towns as they 'reasoned in terms of tax gains without looking at the characteristics of housing and its location' (Scellier \& Le Bouillonnec, 2008: 29). ${ }^{6}$ With relatively low land prices and rent structures not yet fully exploited, buy-to-let investments in these locations provided higher tax returns than in more overheated markets (Scellier \& Le Bouillonnec, 2008). However, local demand for private rental housing units was not always as high as these developers had hoped during the precrisis property boom (Vergriete, 2013, Chapter 8). The local crises of over-production in rural towns such as Albi, Saint-Gaudens, Montauban, Bergerac, Castres and Angoulême illustrate this (Scellier \& Le Bouillonnec, 2008, p. 32). In response to the crisis, the French state introduced a new system of rental ceilings in 2012 to prevent future crises of over-production in smaller cities and regions (Pollard, 2011).

Against this background, it remains a challenge for the French government to stimulate the production of housing and to stabilise the rental levels in overheated market segments (Vergriete, 2013). Since the house prices in metropolitan areas of France are currently increasing beyond pre-crisis levels, an increasing part of the population becomes more reliant on private renting in 
the absence of available alternatives and affordable housing (Lipietz, 2013). In some locations, buy-to-let investments may satisfy both private landlords and renters as financial expectations and demand for new private rental homes can be reconciled. However, buy-to-let investments in other locations may encourage rentierism as private landlords and the real estate industry know how to 'game' rental and fiscal regulations and make renters pay for their investment schemes (Bosvieux, 2011; Pollard, 2011). In case of the latter, little may remain of the democratic promise of privatised Keynesianism as renters are locked out of the benefits of it (Lipietz, 2013).

In sum, these examples show that large amounts of state-subsidised mortgage credit via private landlords and private property developers have been funnelled into the built environment (Lipietz, 2013). Mortgaged homeownership in France may have remained comparatively low with only $40 \%$ as a share of GDP. This number, however, conceals that a large proportion of mortgage credit of commercial banks was actually issued to private landlords and - indirectly - to private property companies and the construction sector. Interestingly, the ascent of private landlordism has hitherto not resulted in a decline of homeownership rates, a trend that can be observed in many posthomeownership societies such as the United Kingdom (Forrest \& Hirayama, 2015; Ronald, Kadi, \& Lennartz, 2015). To the contrary, homeownership rates in France have stabilised and mortgage debt levels are still increasing (Driant, 2010). However, while the number of new private landlords is increasing faster than the number of new homeowners that take up mortgages, it is not unlikely that French-style privatised Keynesianism will evolve into a more regressive phase in the near future: reinforced private landlordism and reduced home ownership.

\section{Discussion and conclusion}

While the resurgence of private landlordism in advanced, capitalist societies is generally accompanied by reduced home ownership and uneven housing opportunities, private landlordism is sometimes perceived as a trend that undermines an important aspect of privatised Keynesianism: asset-based welfare through home ownership (Kemp, 2015; Ronald et al., 2017). Although this paper has recognised this regressive trend in advanced, capitalist societies, it has mobilised the idea that private landlordism is nonetheless an integral part of privatised Keynesianism. First and foremost, this paper has shown that private landlordism was already an important component of pre-crisis privatised Keynesianism as national governments introduced various supplyside subsidies to boost the private rental sector and new housing production (cf. Fernandez \& Aalbers, 2016). Second, it has mobilised the idea that while established homeowners are switching already accumulated housing wealth into the private rental sector, the resurgence of private landlordism is de facto 
a deepening of privatised Keynesianism in another market segment (Kemp, 2015).

In making this argument, this paper has focused on a national case study of the housing system of France. Much like in other European countries, the French government started promoting home ownership in the late 1970s, first among low-income households, later among medium-income households (Aalbers, 2015). However, a more distinctive element of French-style privatised Keynesianism is that the state also encouraged private landlords to invest in the private rental sector and buy-to-let housing (Pollard, 2010b). As such, French-style privatised Keynesianism can be understood as a flexible regime of accumulation that both stimulates housing demand and housing production by linking different kinds of actors and households to each other (Lipietz, 2013). Rather than claiming that the diversified credit model of France was purely emphasized by the state, this paper has also shown that the diversification of credit was a business model which enabled commercial banks and property developers to optimise their profit rates by alternating strategically between mortgage lending and property development (Tutin \& Vorms, 2014).

Although the French housing system appears to be resilient and relatively unexposed to the crisis of 2007-2008 (Tutin \& Vorms, 2014), this paper concludes that French-style privatised Keynesianism is not necessarily a stable growth regime. Overall, it is striking that during the decades of privatised Keynesianism the tight supply of housing units in 'overheated' French metropolitan regions is still prevalent (Trouillard, 2014; Vergriete, 2013). Furthermore, while combined debt levels of homeowners and private landlords are quite high and still increasing, household indebtedness in France is significantly higher than commonly understood (Lipietz, 2013). Also, the French programme of stimulating home ownership and buy-to-let housing has specifically been targeted to medium-income households (Driant, 2010). That is to say, an increasing number of low-income households are excluded from 'trading up the value of their housing assets' in both the owner-occupied and the private rental segment (Watson, 2010). Last but not least, the case of France also shows one of the contradictions of privatised Keynesianism or 'house price Keynesianism': little remains of the initial policy goal to reduce public expenditure to the housing sector now that the expenses of 'personal aid' have reached such heights and now that the state is receiving less tax income due to the provision of 'fiscal aid' (Driant, 2010).

Beyond the French context, this paper concludes that a more fine-grained analysis is required to understand what qualitative transformation post-crisis privatised Keynesianism has undergone in advanced, capitalist societies. In this regard, a preliminary working hypothesis can be that in more liberal countries such as the United Kingdom, the reconstitution of privatised Keynesianism is strongly accompanied by reduced home ownership and 
uneven housing opportunities among generations and families (Kemp, 2015; Ronald et al., 2017). Yet, in more non-liberal countries such as France, home ownership and private landlordism are still co-evolving and rather complement each other. Nonetheless, this paper also acknowledges that once a housing systems reaches the stage of expanded home ownership, arrived homeowners tend to switch their housing wealth into the private rental sector (cf. Arundel, 2017; Lipietz, 2013). Although we can see this second phase of privatised Keynesianism only slowly advancing in France, the ongoing transformations in the UK housing system certainly hold a mirror up to France and other countries (cf. Fernandez \& Aalbers, 2016). The emergence of a new class of property owners that actively engages in the letting out of statesubsidized private rental homes is an important phenomenon that deserves more attention in France (Bosvieux, 2011).

In further investigating the advent and reconstitution of privatised Keynesianism, this paper also points out that it is important not to disregard the legacy of housing policies and domestic policy-making (cf. Jacobs \& Manzi, 2017). As the French case shows, the advent of privatised Keynesianism does not necessarily coincide with a neoliberal restructuring of global finance, but rather relates to fundamental shifts in domestic housing policies that were at first implemented in the 1970s (Driant, 2010). Another important conclusion is that the literature should not only address how global finance pushes homeowners into more debt, but also explore how credit expansion affect the supply-side of housing production, private landlords and private property developers (cf. Romainville, 2017; Van Loon, 2016). Furthermore, the French case shows that as long as a credit supply is targeted at different sectors of the housing economy, credit expansion can unfold in a more balanced and controlled way without necessarily over-leveraging the credit system (Tutin \& Vorms, 2014). Therefore, this paper also calls for more research on 'moderately financialised' national housing systems.

In conclusion, this paper addresses an important issue for future research. In 2009, the French state introduced a new Securitisation Act to boost the secondary mortgage market (Wainwright, 2015). This new investment act lifted previous restrictions to the issuance of securitised debts and also allowed mortgage banks to securitise insurance risks (Birouk \& Cassan, 2012; Segoviano, Jones, \& Lindner, 2015). With a total value of 47 million euro in 2014, the amount of issued real estate-backed securities in the European Union was the highest in France (Hypostat, 2015, p. 106). The Securitisation Act of 2009 may be understood as a new measure to make the French banking sector more competitive (Hardie \& Howarth, 2009; Wainwright, 2015). However, it can also be perceived as a new housing policy of 'liquid aid', where mortgage securitisation is used is as a new political instrument to boost mortgage loans to home owners and private landlords (Segoviano et al., 2015). To what extent this evidence indicates that French-style privatised Keynesianism is currently 
moving faster into the direction of the housing systems of English speaking countries needs to be examined further.

\section{Notes}

1. Translation from French by the author.

2. While in an aging society such as the French a majority of homeowners has already paid off a mortgage, only $30 \%$ of the total number of homeowners was paying an actual mortgage in 2013. The increase of mortgage debt as a percentage of GDP from 20\% in 1995 to 40\% in 2012 is quite substantial in France. Yet, the actual number is still small in comparison with countries such as the Netherlands (110\%), the United Kingdom (85\%), Ireland (85\%) and Sweden (65\%).

3. The temporary increase of 'aid to bricks and mortar' between 2003 and 2010 can be explained by the fact that public housing providers (HLM) in France were allowed to purchase new housing units from private developers. While this increase may appear as a return to post-war housing subsidies, it is rather a form of marketisation not discussed in this paper.

4. Effose (2003) and Blanc (2004) have highlighted that many trends towards marketisation and liberalisation have not solely been induced by the housing reform of 1977, but were already part of the policy agenda from the 1960s onward.

5. Between 2010 and 2011, the PTZ had no income conditions, which explains the curve in Figure 2. The decline of the PTZ in 2013, however, was temporary. After the post-GFC stimulus package had achieved its policy goals between 2009 and 2012, the expansion of the PTZ was halted. However, the introduction of a new tax decree in 2014, the 'Pinel tax allowance', again puts a strong emphasis on the PTZ as a policy instrument. This effect can be seen in Figure 4, which contains more recent data on the PTZ and housing transactions.

6. Translation from French by the author.

\section{Acknowledgments}

I thank Manuel Aalbers, Thibault le Corre, Maximo Isaac Kitever Henao, Arie Stoffelen and the members of my research group for responding to earlier versions of this article or for informing me about France and its housing system. Last but not least, I would like to thank the referees and the editor of this journal for constructive feedback.

\section{Disclosure statement}

No potential conflict of interest was reported by the author.

\section{Funding}

'The Real Estate/Financial Complex' research project (European Research Council [grant number 313376]). 


\section{References}

Aalbers, M.B. (2015). The Great Moderation, the Great Excess and the global housing crisis. International Journal of Housing Policy, 15(1), 43-60.

Aalbers, M.B. (2016). The financialization of housing: A political economy approach. London; New York, NY: Routledge.

Aalbers, M.B., \& Christophers, B. (2014). Centring housing in political economy. Housing, Theory and Society, 31(4), 373-394. doi:10.1080/14036096.2014.947082

Andrews, D., Sánchez, A.C., \& Johansson, A. (2011). Housing markets and structural policies in OECD countries. Paris: OECD Economics Department Working Papers 836.

Arundel, R. (2017). Equity inequity: Housing wealth inequality, inter and intra-generational divergences, and the rise of private landlordism. Housing, Theory and Society, 34(2), 176-200.

Birouk, O., \& Cassan, L. (2012). Securitisation in France. Paris: Banque de France.

Blanc, M. (2004). The changing role of the state in French housing policies: A roll-out without roll-back? European Journal of Housing Policy, 4(3), 283-302.

Blanc, M. (2010). The impact of social mix policies in France. Housing Studies, 25(2), 257-272.

Boccara, L. (2014). Ces promoteurs adossés à des banques [These developers are backed by banks]. Les Echos. Paris: Les Echoes. Retrieved from http://www.lesechos.fr/13/ 02/2014/LesEchos/21626-149-ECH_ces-promoteurs-adosses-a-des-banques.htm

Bosvieux, J. (2005). L'Investissement Locatif: À Qui Profite Le Dispositif Robien? [Buy-to-let investments: Who benefits from the tax incentive of Robien?] Paris: Agence Nationale Pour L'Information Sur Le Logement.

Bosvieux, J. (2011). Incitations fiscales a l'investissement locatif: Succes quantitatif, ciblage imparfait [Tax incentives for rental investment: Quantitative success, imperfect targeting]. Regards Croisés Sur L'économie, 9, 162-171.

Bourdieu, P. (2000). Les structures sociales de l'économie [The social structures of the economy]. Paris: Éditions du Seuil.

Christophers, B. (2013). A monstrous hybrid: The political economy of housing in early twenty-first century Sweden. New Political Economy, 18(6), 885-911.

Crouch, C. (2009). Privatised Keynesianism: An unacknowledged policy regime. British Journal of Politics and International Relations, 11(3), 382-399.

Crédit Foncier. (2017). Quelles sont les motivations des Français qui font le choix de l'investissement locatif en 2017? [What are the motivations of French people that made the choice to invest in buy-to-let housing in 2017?] Paris: Crédit Foncier de France. Retrieved from https://creditfoncier.com/investissement-locatif-2017/

Crouch, C. (2011). What will follow the demise of privatised Keynesianism? The Political Quarterly, 79(4), 1-13.

Cusin, F. (2013). Les prix immobiliers dans les métropoles françaises. Un révélateur de la pénurie de logements? [Real estate prices in French metropolitan regions. A revealer of the shortage of housing?] Revue de l'OFCE, 2(128), 123-162.

Davezies, L. (2012). La crise qui vient. La nouvelle fracture territoriale [The crisis that comes. The new territorial fracture]. Paris: La République des Idées, Seuil.

DGTPE. (2010). Trends in the French housing market. Paris: Direction Générale Du Trésor et de la Politique Économique.

Driant, J.-C. (2010). Les politiques du logement en France [The policies of housing in France]. Paris: La Documentation française. 
Driant, J.-C., \& Li, M. (2012). The ongoing transformation of social housing finance in France: Towards a self-financing system? International Journal of Housing Policy, 12 (1), 91-103.

Effose, S. (2003). L'invention du logement aidé en France: L'immobilier au temps des Trente Glorieuses [The invention of housing aid in France: Real estate in times of the post-war economic miracle]. Paris: Ministère de l'économie, des finances et de l'industrie.

Fernandez, R., \& Aalbers, M.B. (2016). Housing and the variations of financialized capitalism. Competition \& Change, 20(2), 71-88.

Forrest, R., \& Hirayama, Y. (2009). The uneven impact of neoliberalism on housing opportunities. International Journal of Housing Policy, 33(4), 998-1013.

Forrest, R., \& Hirayama, Y. (2015). The financialisation of the social project: Embedded liberalism, neoliberalism and home ownership. Urban Studies, 52(2), 233-244.

Friggit, J. (2011). Quelles perspectives pour le prix des logements après son envolée? [What prospects for the price of housing after its flight?] Regards Croisés Sur L'économie, 1-9.

Gibb, K., \& Nygaard, C. (2005). The impact of buy to let residential investment on local housing markets: Evidence from Glasgow, Scotland. European Journal of Housing Policy, 5(3), 301-326. doi:10.1080/14616710500342218

Gobillon, L., \& le Blanc, D. (2008). Economic effects of upfront subsidies to ownership: The case of the Prêt à Taux Zéro in France. Journal of Housing Economics, 17(1), 133.

Haffner, M., Elsinga, M., \& Hoekstra, J. (2008). Rent regulation: The balance between private landlords and tenants in six European countries. International Journal of Housing Policy, 8(2), 217-233.

Hardie, I., \& Howarth, D. (2009). Die krise but not la crise? The financial crisis and the transformation of German and French banking systems. Journal of Common Market Studies, 47(5), 1017-1039.

Harloe, M. (1995). The people's home? Social rented housing in Europe and America. Hoboken, NJ: Wiley-Blackwell.

Hay, C. (2011). Pathology without crisis? The strange demise of the Anglo-Liberal growth model. Government and Opposition, 46(1), 1-31.

Hypostat. (2015). Hypostat 2015. A review of Europe's mortgage and housing markets. Brussels: European Mortgage Federation.

Insee. (2017). Les conditions de logement en France. Édition 2017 [The housing conditions in France. Edition 2017]. Paris: Institut national de la statistique et des études économiques.

Jacobs, K., \& Manzi, T. (2017). "The party's over": Critical junctures, crises and the politics of housing policy. Housing Studies, 32(1), 17-34.

Jordá, Ò., Schularick, M., \& Taylor, A.M. (2014). The great mortgaging: Housing finance, crises, and business cycles (Working Paper 2014-23). San Francisco, CA: Federal Reserve Bank of San Francisco.

Kemp, P.A. (2015). Private renting after the global financial crisis private renting after the global financial crisis. Housing Studies, 30(4), 601-620.

Kemp, P.A., \& Kofner, S. (2010). Contrasting varieties of private renting: England and Germany. International Journal of Housing Policy, 10(4), 379-398.

Langley, P. (2006). The making of investor subjects in Anglo-American pensions. Environment and Planning D, 24, 919-934.

Les Echoes. (2015). Immobilier: Plus de 42\% des propriétaires-bailleurs reconnaissent avoir eu des litiges avec leur locataire [Real estate: More than $42 \%$ of the private landlords 
admit to have disputes with their tenant]. Paris: Les Echoes. Retrieved from https:// www.lesechos.fr/03/03/2015/lesechos.fr/0204193750067_immobilierplus-de-42-des-

proprietaires-bailleurs-reconnaissent-avoir-eu-des-litiges-avec-leur-locataire.htm

Levy, J.-P., \& Fijalkow, Y. (2010). Chapitre 4 / Les politiques du logement [The politics of housing]. In Olivier Borraz et al. (Eds.), Politiques publiques 2 (pp. 113-138). Paris: Presses de Sciences Po (P.F.N.S.P).

Lipietz, A. (2013). Le tribut foncier urbain aujourd'hui: Le cas de la France [The urban land tribute today: The case of France]. Les Cahiers Marxistes, (243), 1-15.

Nexity. (2015). Document de référence 2014-2015 [Annual report 2014-2015]. Paris: Nexity. Retrieved from http://www.bonduelle.com/fileadmin/user_upload/SITE_ CORPO/FINANCE/Document_de_reference/Bonduelle_DDR_2014-2015_MEL.pdf

Pollard, J. (2007). Les grands promoteurs immobiliers français [The large French property developers]. Flux, 3(69), 94-108.

Pollard, J. (2010a). How the state is handling the property crisis in France: A perspective on recent government measures. International Journal of Urban and Regional Research, 34(3), 686-692.

Pollard, J. (2010b). Soutenir le marché: Les nouveaux instruments de la politique du logement [Supporting the market: The new instruments of the policies of housing]. Sociologie Du Travail, 52, 323-339.

Pollard, J. (2011). Les groupes d'intérêt vus du local. Les promoteurs immobiliers dans le secteur du logement en France [Interest groups seen from the local level. Real estate developers inthe housing sector in France]. Revue Française de Science Politique, 61(4), 681-705.

Romainville, A. (2017). The financialization of housing production in Brussels. International Journal of Urban and Regional Research. 41(4), 623-641. doi:10.1111/14682427.12517

Ronald, R. (2008). The ideology of home ownership. Homeowner societies and the role of housing. Basingstoke: Palgrave-Macmillan.

Ronald, R., \& Kadi, J. (2016). The revival of private landlords in Britain's post-homeownership society. New Political Economy. Advance online publication. doi:10.1080/ 13563467.2017.1401055

Ronald, R., Kadi, J., \& Lennartz, C. (2015). Homeownership-based welfare in transition. Critical Housing Analysis, 2(1), 52-64.

Ronald, R., Lennartz, C., \& Kadi, J. (2017). Whatever happened to asset-based welfare? Shifting approaches to housing wealth and welfare security. Policy \& Politics, 45(2), 173-193.

Sanfelici, D., \& Halbert, L. (2016). Financial markets, developers and the geographies of housing in Brazil: A supply-side account. Urban Studies, 53(7), 1465-1485.

Scellier, F., \& Le Bouillonnec, J.-Y. (2008). Rapport D'Information sur l'evaluation des dispositifs fiscaux d'encouragement à l'investissement locatif [Information report on the evaluation of the tax incentives in favour of buy-to-let housing]. Paris: Assemblée Nationale. No. 1088.

Schwartz, H., \& Seabrooke, L. (Eds.). (2009). The politics of housing booms and busts. New York, NY: Palgrave Macmillan.

Segoviano, M., Jones, B., \& Lindner, P. (2015). La relance de la titrisation. Revue de la stabilité financière no 19 [The revival of securitisation. Review of financial stability no. 19]. Paris: Banque de France.

Shonfield, A. (1965). Modern capitalism. The changing balance of public and private power. Oxford: Oxford University Press. 
Soaita, A.M., Searle, B.A., Mckee, K., Moore, T., Mihaela, A., Searle, B.A., ... Moore, T. (2017). Becoming a landlord: Strategies of property-based welfare in the private rental sector in Great Britain. Housing Studies, 32(5), 613-637.

Soederberg, S. (2017). The rental housing question: Exploitation, eviction and erasures. Geoforum. Advance online publication. doi:10.1016/j.geoforum.2017.01.007

Timbeau, X. (2013). Les Bulles « Robustes » Pourquoi il faut construire des logements en région Parisienne [The 'Robust' Bubble. Why we must build homes in the Paris region]. Revue de l'OFCE / Débats et Politiques, 128, 277-313.

Trouillard, E. (2014). La production de logements neufs par la promotion privée en Île-deFrance (1984-2012): Marchés immobiliers et stratégies de localisation [The production of new housing by private property developers in the Greater Paris region (19842012): Real estate markets and locational strategies]. Paris: Université Paris Diderot Paris 7.

Tutin, C., \& Vorms, B. (2014). French housing markets after the subprime crisis: From exuberance to resilience. Journal of Housing and the Built Environment, 29, 277-298.

Van Loon, J. (2016). Patient versus impatient capital: The (non-)financialization of real estate developers in the Low Countries. Socio-Economic Review, 14(4), 709-728.

Vergriete, P. (2013). La ville fiscalisée: Politiques d'aide à l' investissement locatif, nouvelle filière de production du logement et recomposition de l'action publique locale en France (1985-2012) [The fiscalised city: Buy-to-let housing policies, new chain of housing production and recomposition of local public action in France (19852012)]. Paris: Université Paris-Est. Architecture, Space Management.

Wainwright, T. (2009). Laying the foundations for a crisis: Mapping the historico-geographical construction of residential mortgage backed securitization in the UK. International Journal of Urban and Regional Research, 33(2), 372-388.

Wainwright, T. (2015). Circulating financial innovation: New knowledge and securitization in Europe. Environment and Planning A, 47(8), 1643-1660.

Waldron, R., \& Redmond, D. (2017). "We're just existing, not living!" Mortgage stress and the concealed costs of coping with crisis. Housing Studies, 32(5), 584-612.

Watson, M. (2010). House price Keynesianism and the contradictions of the modern investor subject. Housing Studies, 25(3), 413-426.

Wijburg, G., \& Aalbers, M.B. (2017a). The alternative financialization of the German housing market. Housing Studies, 32(7), 968-989.

Wijburg, G., \& Aalbers, M.B. (2017b). The internationalization of commercial real estate markets in France and Germany. Competition \& Change, 21(4), 301-320. 